Société d'histoire de la révolution de 1848 et des

révolutions du XIXe siècle

2 | 1986

Varia

\title{
Aspects sociaux de l'archéologie et de l'histoire industrielles : l'exemple de la Dordogne
}

\section{Yvon Lamy}

\section{OpenEdition \\ Journals}

Electronic version

URL: http://journals.openedition.org/rh19/12

DOI: $10.4000 /$ rh 19.12

ISSN: 1777-5329

\section{Publisher}

La Société de 1848

\section{Printed version}

Date of publication: 1 June 1986

ISSN: 1265-1354

\section{Electronic reference}

Yvon Lamy, « Aspects sociaux de l'archéologie et de l'histoire industrielles : l'exemple de la Dordogne », Revue d'histoire du XIXe siècle [Online], 2 | 1986, Online since 09 September 2008, connection on 20 April 2019. URL : http://journals.openedition.org/rh19/12 ; DOI : 10.4000/rh19.12

This text was automatically generated on 20 April 2019

Tous droits réservés 


\section{Aspects sociaux de l'archéologie et de l'histoire industrielles : l'exemple de la Dordogne}

Yvon Lamy

\section{ABSTRACTS}

No abstract available by now

Pas de résumé disponible actuellement

INDEX

Mots-clés: Archéologie, Histoire sociale, Industrie 